\title{
RESPONSE OF COCONUT AND COFFEE TO FERTILIZERS APPLIED ON EITHER OR BOTH CROPS IN AN INTERCROPPING SYSTEM
}

By

\author{
R.Z. Margate, J.N. Maravilla, R.M. Ebuna \& M.N. Eroy ${ }^{1}$
}

\begin{abstract}
A study to assess the effects of fertilizer application on either coconut or coffee or both, in an intercropping system was conducted from 1985 to 1991. at the Davao Research Center, Mindanao, Philippines. The coconuts were planted at $8 \mathrm{~m}$ x $8 \mathrm{~m}$ square system.

Fertilizer application on coconut intercropped with either fertilized or unfertilized coffee increased copra yield significantly. A very slight increase in copra per nut was noted on un-fertilized coconut even with fertilized coffee intercrop indicating coconut did not benefit from the fertilizers applied on coffee. Bean yield of fertilized coffee was increased significantly by 202 percent under fertilized or unfertilized coconuts. But yield of unfertilized coffee did not increase even under fertilized coconut. There is a need to apply fertilizers separately to both crops.
\end{abstract}

Economic analysis revealed that fertilizer application to both coconut and coffee gave the highest net return, followed by fertilizer application on coffee alone.

\section{INTRODUCTION}

Observations show that most of the small coconut farmers who practice intercropping apply fertilizers only on the intercrop. Even among the big-time coconut farmers, not all of them apply fertilizers to both coconut and intercrop. In other countries like Tanzania and Fiji, fertilizer application on intercrops only is the common practice (personal communications).

This practice is resorted to especially when the price of copra is very low and inputs are high. But consideration has to be made on this point because while the farmers want to curb out expenses in the farm, there is a big national interest to protect in the Philippines, i.e. to maintain the country's trade position of copra in the world market and earn more dollar in the process.

There are no reported cases yet that in intercropping systems involving coconut, fertilizer application only to one crop would benefit the other crop. Results of earlier studies at the Philippine Coconut Authority, however, show that when both coconut and intercrops were fertilized, the yield of coconuts in a multi-storey cropping pattern with three intercrop combination significantly increased over those coconut without intercrop (Margate and Magat, 1983). Felizardo (1983) suggested that in intercropping there should be separate fertilization program for both coconut and intercrop based on their individual recommendation as if they are not planted in the same area.

This study was conducted to know whether the fertilizer applied on the coconut would benefit the coffee intercrops or vice versa.

\footnotetext{
${ }^{1}$ PCA-Davao Research Center, Bago Oshiro, Davao City, Philippines.
} 


\section{MATERIALS AND METHODS}

\section{Experimental palms/area}

About 25-30 years old 'Laguna' tall palms, distanced $8 \times 8 \mathrm{~m}$ square were used in the study. The palms were planted in a Tugbok clay loam soil (Alfisol) on a slightly sloping and well-drained area. The palms were regularly fertilizer yearly (for those treatments requiring fertilizer) with $1.5 \mathrm{~kg}$ Ammonium sulfate $+1.6 \mathrm{~kg} \mathrm{KCl}$. However, prior to this experiment the palms used were uniformly fertilized in the earlier studies conducted on the same area, hence were productive $>75$ nuts per tree per year).

\section{Intercrop}

Robusta coffee variety was used as intercrop in view of its availability and wide acceptance by farmers.

Plastic-bagged seedlings were obtained from the Bureau of Plant Industry. They were planted in two rows in between coconut rows in a triangular pattern. For those requiring fertilizers, the coffee intercrop was fertilized with 14-14-14 in the first two years at the rate of 200 and $250 \mathrm{~g}$ per hill per year, respectively, and the amount was increased by $50 \mathrm{~g}$ per year until the fifth year. Thereafter, ammonium sulfate was used at $600 \mathrm{~g}$ per hill as the coffee trees showed low levels of $\mathrm{N}$ and $S$.

\section{Treatments}

The treatments were the following:

1. coconut unfertilized + coffee unfertilized

2. coconut unfertilized + coffee fertilized

3. coconut fertilized + coffee unfertilized

4. coconut fertilized + coffee fertilized

\section{Experimental Design}

The above treatments were arranged in a randomized complete block design i $\mathrm{n}$ three replications. Nine palms per plot which were completely surrounded with 48 coffee hills composed the experimental unit.

\section{Data Gathered}

For coconuts, number of nuts per tree per year, copra weight per nut, copra per palm per year and yearly leaf analysis were taken.

For coffee, yield data, number of lateral branches, number of leaves of two opposite lateral median branches and leaf analysis were gathered yearly. Soil analysis was taken at the end of the study.

Simple cost-benefit analysis was made during the latest year of production. 


\section{RESULTS AND DISCUSSION}

\section{Coconut Production}

The average nut production of palms did not differ significantly among treatments. (Table 1 and Appendix Table 1). In a well-nourished coconut (the palms used in this study were previously fertilized), further addition of fertilizer did not bring about a dramatic increase in the number of nuts as nut production was already high even in the control plots.

More apparent response to the different treatments was noted on the copra weight per nut (Table 1) which started in the second year of observation (Appendix Table 2). The weight of copra per nut was low in unfertilized palms (treatments 1 and 2) even if the coffee intercrop was fertilized (treatment 2) indicating that the coconut did not benefit from the fertilizer applied on the coffee intercrop. Although there was a slightly heavier copra weight per nut (3.4\% increase) suggesting that it might have absorbed some of the fertilizer nutrients applied on coffee, such increase was not significant. On the other hand, there was undoubtedly higher copra weight per nut of 220.4 to 224.0 $\mathrm{g}$ in treatments 3 and 4 (fertilized coconuts) compared to treatments 1 and 2.

On copra weight per palm per year (Table 1 and Appendix Table 3) the same trend of response was observed as in copra weight per nut. In fertilized coconuts, either with or without fertilizer application on coffee, copra yield per palm increased significantly over the unfertilized ones ranging from 12-19 percent. This was consistent over the years and was also observed on the seven year average yield. On the other hand, copra yield per palm of unfertilized coconut with fertilized coffee (treatment 2) did not differ significantly with the control indicating that again, the coconut had not benefited from the fertilizers applied on coffee intercrop. This suggests for a separate fertilization of both crops.

CW12

Table 1. Annual average nut and copra yield of palms in relation to different treat ments (average 7 years)

\begin{tabular}{|c|c|c|c|}
\hline TREATMENTS & $\begin{array}{c}\text { NUT/PALM } \\
\text { (no.) }\end{array}$ & $\begin{array}{c}\text { COPRA/NUT } \\
(\mathrm{g})\end{array}$ & $\begin{array}{c}\text { COPRA/PALM } \\
(\mathrm{kg})\end{array}$ \\
\hline 1. Coco unfert. + coffee unfert. & 114.4 & $199.7 \mathrm{c}$ & $22.8 b$ \\
\hline 2. Coco unfert. + coffee fert. & 109.1 & $101.4 \mathrm{bc}$ & $110.5 b$ \\
\hline 3. Coco fert. + coffee unfert. & 114.7 & $116.6 \mathrm{a}$ & $124.7 \mathrm{a}$ \\
\hline 4. Coco fert. + coffee fert. & 118.3 & $119.6 \mathrm{ab}$ & $117.5 \mathrm{a}$ \\
\hline $\begin{array}{ll}\text { LSD } & 0.05\end{array}$ & ns & 16.7 & 2.6 \\
\hline 0.01 & ns & ns & $\mathrm{ns}$ \\
\hline C.V. $\quad(\%)$ & 8.1 & 5.6 & 7.7 \\
\hline
\end{tabular}

Ns - not significant

Means having the same letter are not significantly different at 5\% level (LSD).

\section{Growth and Yield of Coffee}

About 32-38 percent of the coffee trees from the unfertilized plots died during the first two years which could be due to nutritional problem (Table 2). With their limited root systems, the coffee plants could not intercept the fertilizers applied on coconut. In fact, the remaining plants had to be supplied with a handful of fertilizers just to let them recover and survive (Fig. 1). It was found in 1987 by Dr. S.S. Magat through foliar diagnosis that the experimental coffee trees suffered severe def iciency in nitrogen and sulfur, hence, the application of $\left(\mathrm{NH}_{4}\right)_{2} \mathrm{SO}_{4}$. 
Table 2. Percentage mortality of coffee 1.5 years after planting

\begin{tabular}{|l|c|}
\hline \multicolumn{1}{|c|}{ Treatment } & \% Mortality \\
\hline 1. Coco unfert + coffee unfert. & 38.1 \\
2. Coco unfert + coffee fert & 13.3 \\
3. Coco fert + coffee unfert. & 32.4 \\
4. Coco fert + coffee fert. & 17.1 \\
\hline
\end{tabular}

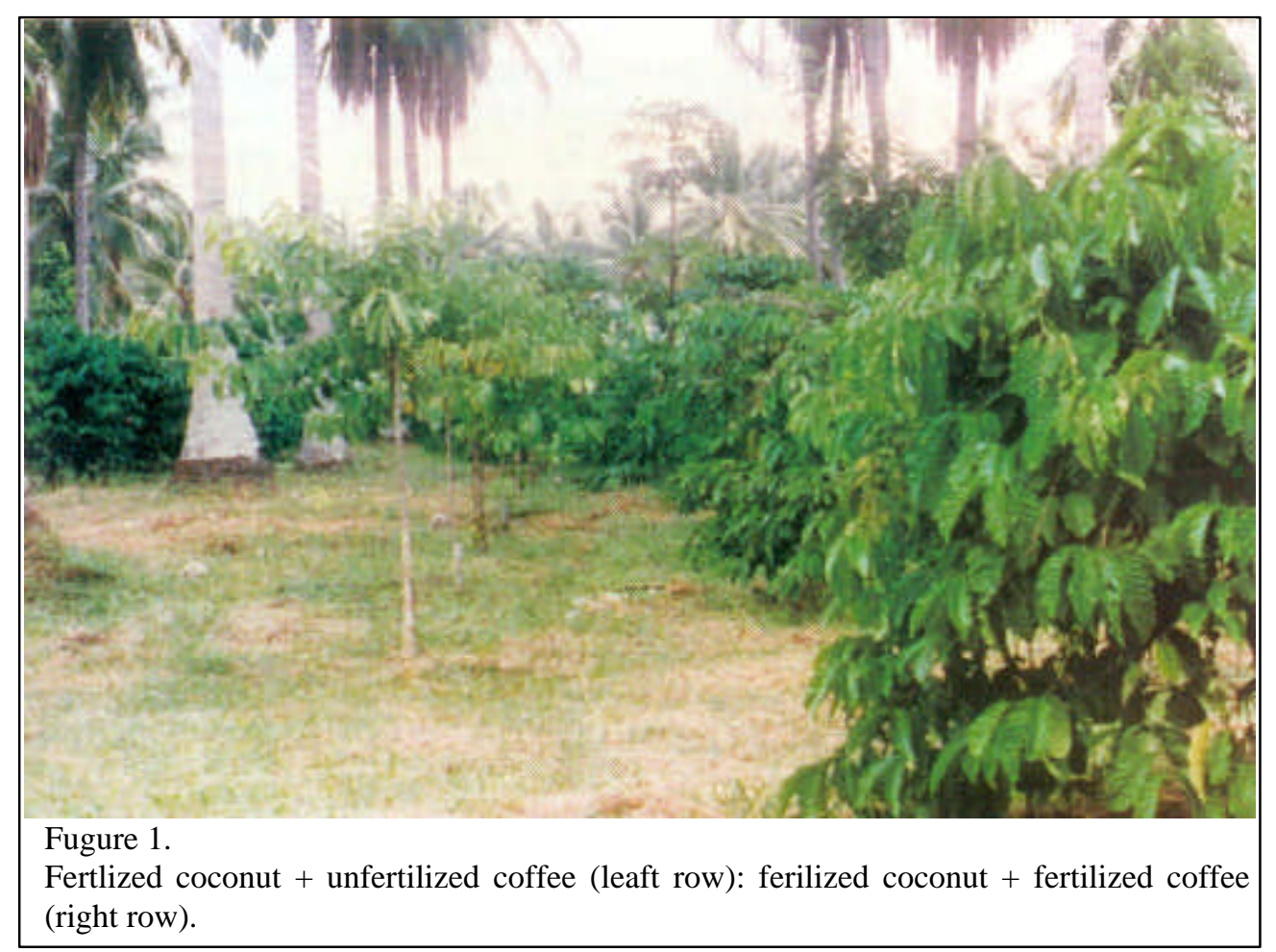

On the yield of coffee, fertilizer application increased the yield significantly over the unfertilized ones by 202 percent (Table 3). Otherwise, even if coconut was fertilized, the coffee yield did not increase indicating further that the coffee plants could not benefit from the fertilizers applied on the coconut.

Between the two fertilized coffee treatments (treatments 2 and 4), a significant difference especially on the yearly average bean yield was observed. The latter, with fertilized coconut, being higher than the former, with unfertilized coconut. It is likely that competition for plant nutrients had taken place between fertilized coffee and the unfertilized coconut in treatment 2 which could have depressed coffee yield and slightly increased copra weight per nut (Table 1).

The significant increase in the yield of fertilized coffee over the unfertilized ones (under both fertilized and unfertilized coconut) was accompanied by more number of coffee leaves in these treatments (Table 4).

\section{Leaf Nutrient}

Coconut - Clear evidence of response to fertilizer application on the leaf nutrient contents was noted only in $\mathrm{Cl}$, especially in the later years (Fig. 2). The leaff $\mathrm{Cl}$ levels increased in palms which received fertilizers (Treatments 3 and 4) which may further explain for the slight increase in 
the copra weight of coconut in these treatments. For other elements like $\mathrm{N}$ and $\mathrm{S}$, no response was noted even if these elements were applied in some of the treatments, suggesting that these were not limiting as far as coconut is concerned. Although, there were significant differences in leaf levels of some elements in some years of observation, no definite trend could be established in relation to the fertilizers applied.

Table 3. Annual yield of coffee ( $\mathrm{kg}$ fresh wt/hill)

\begin{tabular}{|c|c|c|c|c|c|c|c|}
\hline \multirow{2}{*}{\multicolumn{2}{|c|}{ Treatment }} & \multicolumn{6}{|c|}{ Year } \\
\hline & & 3 & 4 & 5 & 6 & 7 & Average \\
\hline Coco & ee unfert & $0.31 b c$ & $0.63 b$ & $0.44 \mathrm{c}$ & $0.49 b$ & $1.18 \mathrm{~b}$ & $0.61 \mathrm{c}$ \\
\hline Coco & ee fert & $0.56 \mathrm{~b}$ & $1.61 \mathrm{a}$ & $1.32 \mathrm{~b}$ & $1.45 \mathrm{a}$ & $3.02 \mathrm{a}$ & $1.59 b$ \\
\hline Coco & unfert & $0.18 \mathrm{c}$ & $1.08 \mathrm{ab}$ & $0.41 \mathrm{c}$ & $0.53 b$ & $0.81 b$ & $0.60 \mathrm{c}$ \\
\hline Coco & fert & $0.94 \mathrm{a}$ & $1.73 \mathrm{a}$ & $2.04 \mathrm{a}$ & $1.52 \mathrm{a}$ & $4.06 \mathrm{a}$ & $2.06 \mathrm{a}$ \\
\hline LSD & 0.05 & 0.346 & 0.863 & 0.592 & 0.497 & 1.070 & 2.254 \\
\hline & 0.01 & 0.524 & ns & 0.897 & 0.754 & 1.62 & 0.385 \\
\hline C.V. & $(\%)$ & 34.90 & 34.30 & 38.20 & 25.00 & 23.60 & 14.80 \\
\hline
\end{tabular}

ns - not significant

Means having the same letter are not significantly different at $5 \%$ level, (LSD).

Table 4. Growth of coffee as affected by the different treatments (1991)

\begin{tabular}{|c|c|c|c|c|}
\hline \multirow{2}{*}{ TREATMENT } & \multicolumn{2}{|c|}{ No.of Lateral Brances } & \multicolumn{2}{|c|}{$\begin{array}{l}\text { No.of leaves of two Opp } \\
\text { Median Branches }\end{array}$} \\
\hline & $1^{\text {st }}$ index & $2^{\text {nd }}$ index & $1^{\text {st }}$ index & $2^{\text {nd }}$ index \\
\hline Coco unfert + coffee unfert. & 18.3 & 17.4 & $20.2 b$ & $22.5 b$ \\
\hline Coco unfert. + coffee fert. & 18.4 & 17.8 & $70.5 \mathrm{a}$ & $65.5 \mathrm{a}$ \\
\hline Coco fert. + coffee unfert & 15.7 & 14.4 & $21.7 \mathrm{~b}$ & $21.8 b$ \\
\hline Coco fert. + coffee fert. & 18.1 & 18.1 & $69.2 \mathrm{a}$ & $66.8 \mathrm{a}$ \\
\hline LSD $\quad 0.05$ & ns & ns & 7.80 & 9.13 \\
\hline 0.01 & - & - & 11.82 & 13.83 \\
\hline C.V. & 45.00 & 45.50 & 8.60 & 10,40 \\
\hline
\end{tabular}

Ns - not significant

Means having the same letter are not significantly different at 5\% level (LSD).

Coffee - There was an apparent increase in the leaf $\mathrm{N}$ levels for those plots applied with ammonium sulfate (Fig. 3). The positive response to $\mathrm{N}$ application clearly demonstrated its high requirement for it. The application of ammonium sulfate, likewise, improved leaf-S level confirming preliminary observations that the limiting elements for coffee in the area are $\mathrm{N}$ and S (Fig. 4). The increase in $\mathrm{S}$, however, is accompanied with low levels of $\mathrm{Cl}$ and $\mathrm{B}$ implying possible existing antagonism between $\mathrm{S}$ and $\mathrm{Cl}$ and $\mathrm{S}$ and $\mathrm{B}$.

The cof fee absorbed $\mathrm{N}, \mathrm{K}$ and $\mathrm{Cl}$ in large quantities, while coffee absorbed $\mathrm{N}, \mathrm{K}, \mathrm{Ca}$ and $\mathrm{Mg}$ most, hence a separate fertilizer application and formulation for each crop when planted together in an intercropping system. 


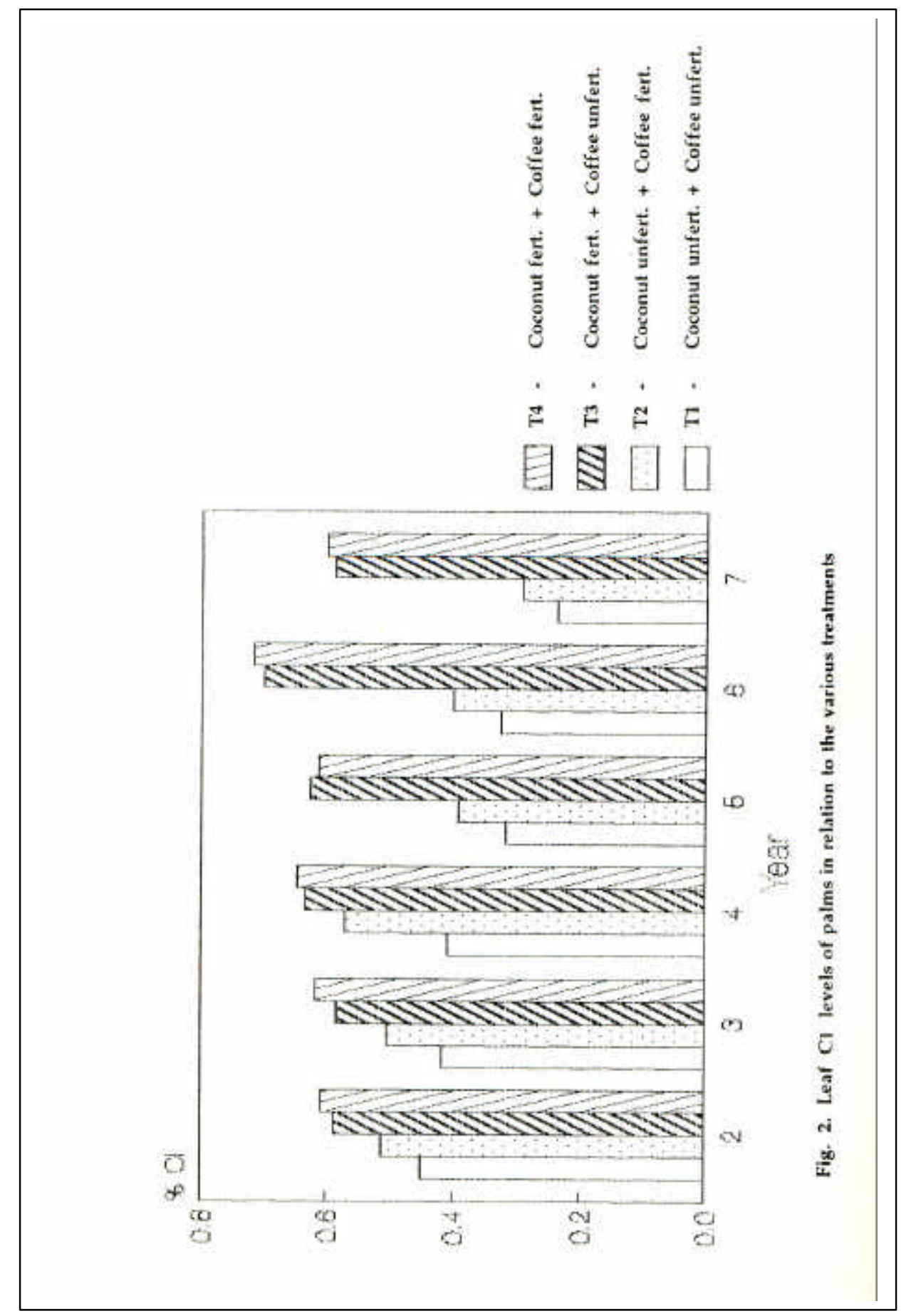

\section{Economic Implication}

Under the economic condition of 1991, the highest combined net profit from coconut and coffee of P26,987 per hectare per year was obtained from treatment 4 when both crops were fertilized (Table 5). This was followed by treatment 2 with coffee alone being fertilized giving net profit of P20,752. Without fertilizer application on both coconut and coffee (control), a net income of P13,723 was realized. As mentioned earlier, coconuts used in this study previously received blanket application of fertilizer making them still productive. Long-term nonapplication of fertilizer to coconut will eventually be detrimental to coconut production due to depletion of soil nutrient reserves. Magat et al. (1993) reported at least two years positive residual effects on coconut yield after three to five years of regular application of $\mathrm{C} 1$ fertilizers. In this particular study, the 
non-application of fertilizer to coffee either with or without fertilizer application on coconut produced a negative return when coffee income alone was considered which pulled down the combined net profit of both crops.

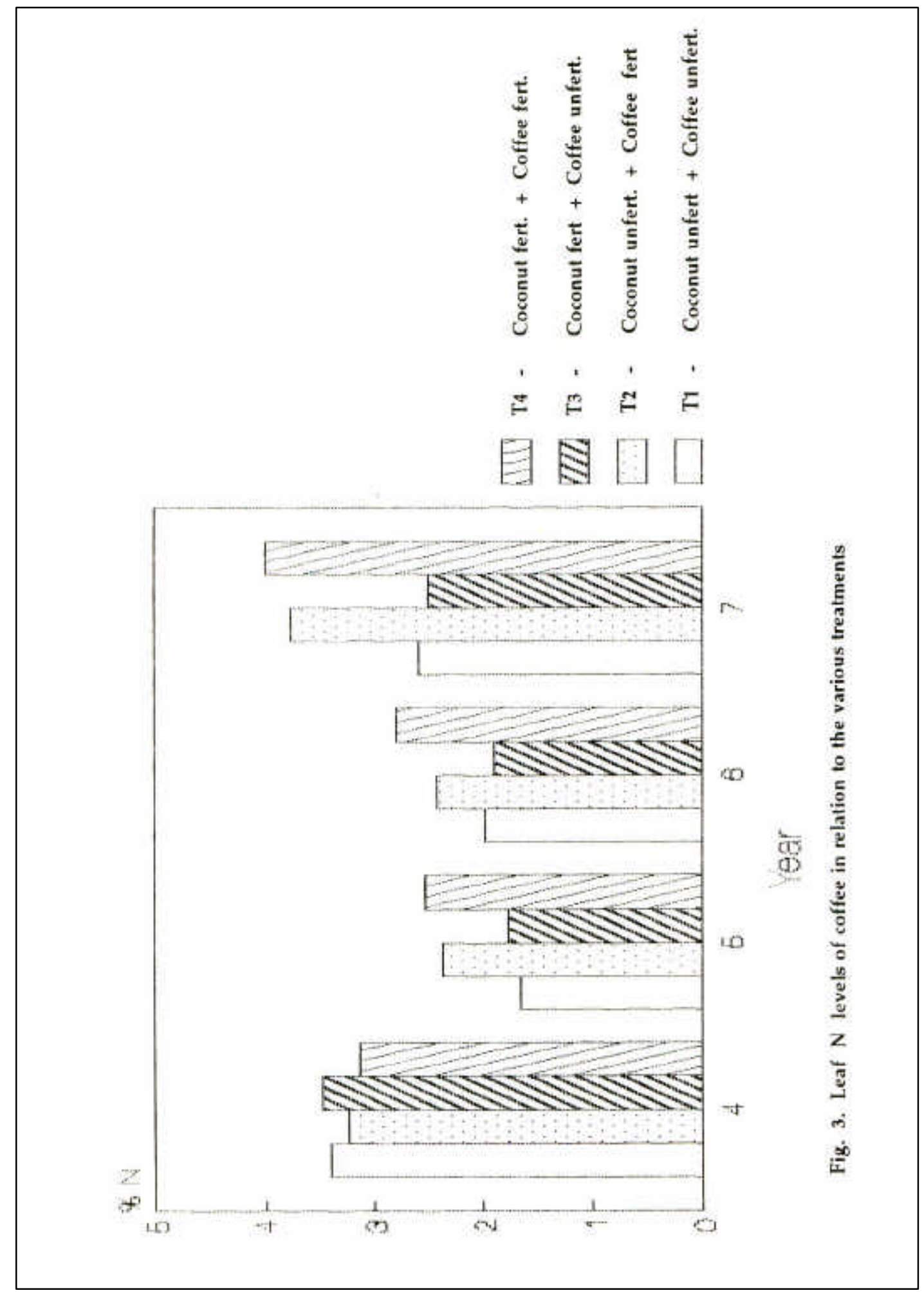




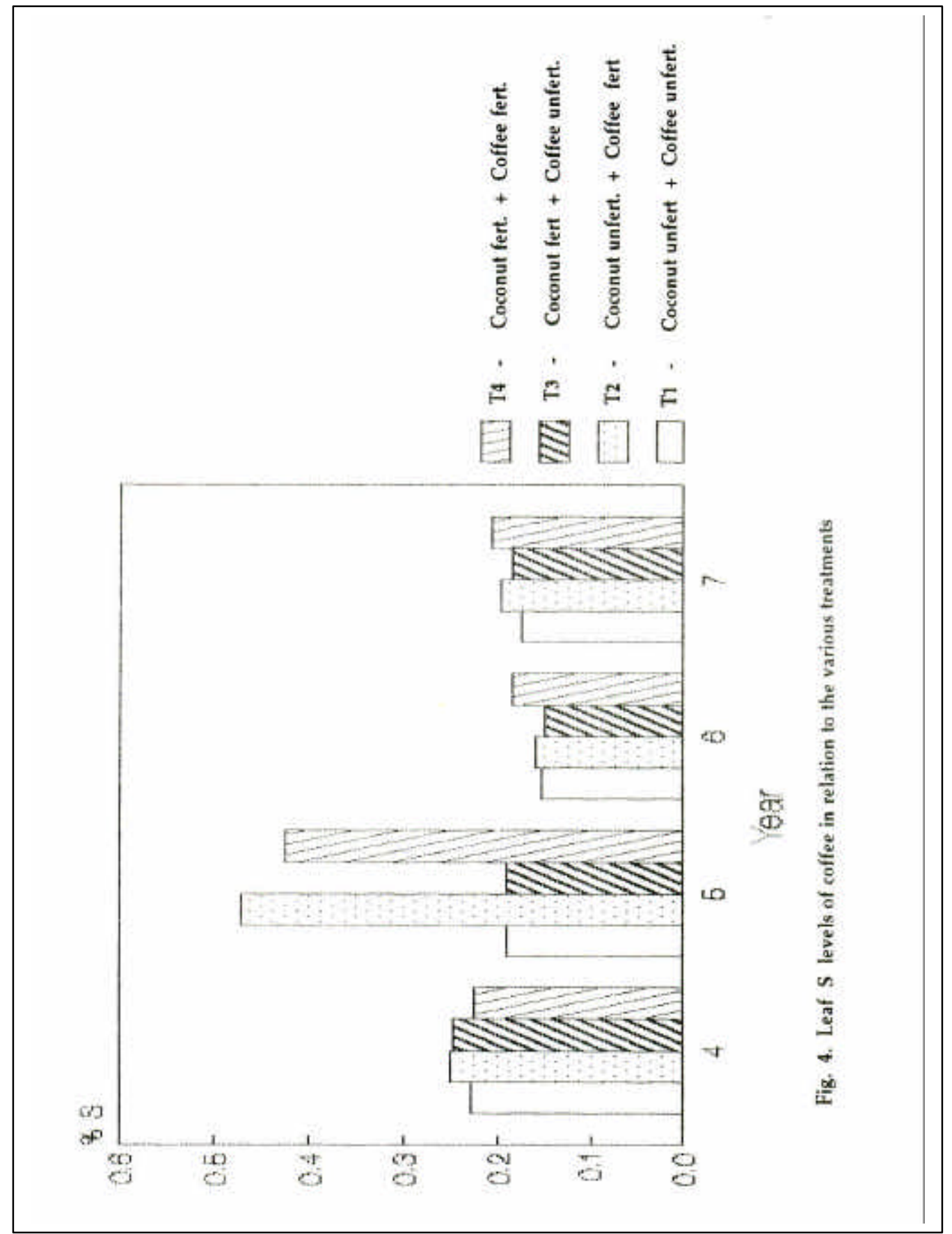

Table 5. Economic analysis (1991) per hectare

\begin{tabular}{|l|r|r|r|r|r|r|}
\hline \multirow{2}{*}{ Treatment } & \multicolumn{1}{c|}{$\begin{array}{c}\text { Copra } \\
\text { yield } \\
\text { kg/ha }\end{array}$} & \multirow{2}{*}{$\begin{array}{c}\text { Coffee } \\
\text { yield } \\
\mathrm{kg} / \mathrm{ha}\end{array}$} & \multicolumn{2}{|c|}{ Gross $^{1 /}$ Income cost } & \multicolumn{2}{|c|}{ Total $^{2 /}$ Comb. net } \\
\cline { 5 - 7 } & & & \multicolumn{1}{c|}{$(\mathrm{P})$} & \multicolumn{1}{c|}{$(\mathrm{P})$} & \multicolumn{1}{|c|}{ Benefit } & MBCR \\
\hline Coco unfert+ coffee unfert. & 2,574 & 237.9 & 20,392 & 6,669 & 13,723 & \\
Coco unfert.+ coffee fert. & 2,672 & 608.8 & 28,775 & 8,023 & 0,752 & 6.19 \\
Coco fert. + coffee unfert & 3,307 & 163.3 & 23,423 & 7,667 & 15,756 & 3.03 \\
Coco fert. + coffee fert. & 3,276 & 818.4 & 36,007 & 9,021 & 26,987 & 6.64 \\
\hline
\end{tabular}




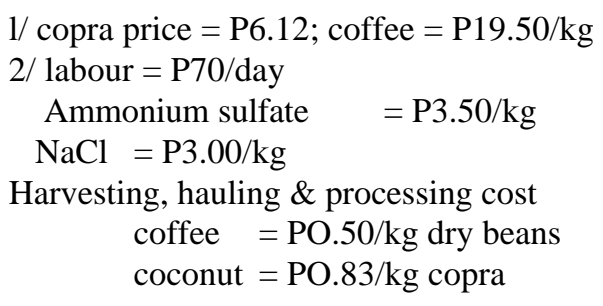

\section{CONCLUSION AND RECOMMENDATION}

In an intercropping system involving coconut and coffee, fertilizer application on either crop increased only the yield of the fertilized crop but does not benefit the other. However, unfertilized coconut (owing to its extensive rooting system) tends to compete for nutrients with the fertilized coffee intercrops reducing the yield of the latter even if the coconut does not significantly benefit in the process in terms of yield improvement.

Hence, there is a need to apply fertilizers separately to both crops based on their individual requirements to make the farming system more productive and profiTable. Applying the fertilizer only on coffee may be adopted as a second option but not without caution, i.e. it should not be a prolonged practiced and should be adopted only on previously well-nourished coconut.

\section{ACKNOWLEDGMENT}

The authors wished to extend their sincere gratitude to the people who contributed their hands, hearts and minds in the realization of this work especially the following:

The able but humble field and laboratory men of Agro-Soils Division headed by Mr. Edilberto G. Cuison for their invaluable assistance in data collection, maintenance, fertilization and other related works.

Ms. Gloria C. Palcis and Messrs. Felix Largo and Salvador Abendan for the graphics and computerization works.

Dr. Severino S. Magat for reviewing the draft of the manuscript and whose comments and suggestions enhanced the final paper.

The Department Manager of PCA-Davao Research Center Mr. Romero C. Blancaver for the much needed support and encouragement and the occasional pat on the shoulder.

Lastly to HIM for sustaining us through the years. 


\section{REFERENCES}

FELIZARDO, B.C., 1983. Cultural management practices in coconut-based farming systems. Proc. Symposium on coconut-based farming systems. VISCA, Leyte.

MAGAT, S.S., G.G. PADRONES and L.M. ALFORJA. 1983. Residual effects of three chloride fertilizers on the yield and leaf nutrient levels of coconut grown on an inland soil of Davao (Mindanao, Philippines). Oleagineux. 48(5): 237-241

MARGATE, R.Z. and S.S. MAGAT. 1983. Coconut-based multi-storey cropping. Phil. J. Crop. Sci. $8(2): 81-86$.

Personal communications. 1992. From Julius Mugines, a trainee from Tanzania.

Appendix Table 1. Nut production of palm in reLation to the different treatments.

\begin{tabular}{|c|c|c|c|c|c|c|c|c|c|}
\hline \multirow{2}{*}{\multicolumn{2}{|c|}{ Treatment }} & \multicolumn{8}{|c|}{ Year } \\
\hline & & 1 & 2 & 3 & 4 & 5 & 6 & 7 & Ave. \\
\hline \multirow{2}{*}{\multicolumn{2}{|c|}{$\begin{array}{l}\text { Coco unfert + coffee unfert } \\
\text { Coco unfert + coffee fert }\end{array}$}} & 126.2 & $115.2 \mathrm{C}$ & 112.3 & 112.0 & 119.4 & 101.3 & 101.6 & 114.4 \\
\hline & & 109.1 & 101.4 & 110.5 & 105.7 & 118.2 & 102.8 & 106.9 & 107.0 \\
\hline \multicolumn{2}{|c|}{ Coco fert + coffee unfert } & 114.7 & 116.6 & 124.7 & 108.6 & 132.2 & 112.6 & 115.0 & 118.2 \\
\hline \multicolumn{2}{|c|}{ Coco fert + coffee fert } & 118.3 & 119.6 & 117.5 & 104.9 & 133.3 & 100.8 & 113.5 & 115.8 \\
\hline \multirow[t]{2}{*}{ LSD } & 0.05 & ns & ns & ns & ns & ns & ns & ns & ns \\
\hline & 0.01 & - & - & - & - & - & - & - & - \\
\hline C.V. & $(\%)$ & 12.7 & 13.5 & 8.8 & 10.6 & 17.8 & 9.4 & 10.2 & 8.1 \\
\hline
\end{tabular}

ns - not significant

Appendix Table 2. Copra production per nut in relation to the different treatments

\begin{tabular}{|c|c|c|c|c|c|c|c|c|c|}
\hline \multirow{2}{*}{\multicolumn{2}{|c|}{ Treatment }} & \multicolumn{7}{|c|}{ Year } & \multirow[b]{2}{*}{ Ave. } \\
\hline & & 1 & 2 & 3 & 4 & 5 & 6 & 7 & \\
\hline \multirow{2}{*}{\multicolumn{2}{|c|}{ Coco unfert + coffee unfert }} & & & & gram & & & & \\
\hline & & 190.7 & $216.7 b$ & $205.7 b$ & $203.8 \mathrm{c}$ & $200.7 b$ & $181.4 \mathrm{C}$ & $201.0 \mathrm{c}$ & 199.7 \\
\hline \multicolumn{2}{|c|}{ Coco unfert + coffee fert } & 192.6 & 232.3ab & $208.5 a b$ & $209.6 \mathrm{bc}$ & 213.1ab & $183.2 \mathrm{bc}$ & 207.0bc & 206.6 \\
\hline \multicolumn{2}{|c|}{ Coco fert + coffee unfert } & 200.2 & $240.7 a$ & $226.9 a$ & $234.8 \mathrm{a}$ & $234.9 a$ & $206.7 a$ & $229.2 a b$ & 224.0 \\
\hline \multicolumn{2}{|c|}{ Coco fert + coffee fert } & 188.7 & $252.7 \mathrm{a}$ & $225.0 \mathrm{a}$ & $225.2 a b$ & $226.8 \mathrm{a}$ & $203.7 a b$ & $230.8 a$ & 220.4 \\
\hline \multirow[t]{2}{*}{ LSD } & 0.05 & ns & 21.4 & 18.6 & 16.5 & 25.3 & 22.4 & 17.4 & 16.7 \\
\hline & 0.01 & - & 32.4 & ns & 25.1 & ns & ns & 26.4 & ns \\
\hline C.V. & $(\%)$ & 4.9 & 6.4 & 6.1 & 5.4 & 8.2 & 8.2 & 5.6 & 5.6 \\
\hline
\end{tabular}

ns - not significant

Means having the same letter are not significantlydifferent at 5\% level (LSD) 
Appendix Table 3. Copra yield per tree in relation to the different treatments.

\begin{tabular}{|c|c|c|c|c|c|c|c|c|}
\hline \multirow[t]{2}{*}{ Treatment } & \multicolumn{8}{|c|}{ Year } \\
\hline & 1 & 2 & 3 & 4 & 5 & 6 & 7 & Ave. \\
\hline & \multicolumn{8}{|c|}{ kilogram } \\
\hline Coco unfert + coffee unfert & 24.1 & $24.7 a b$ & 23.1b & $22.8 a b$ & $23.9 b$ & $18.4 b$ & $16.5 b$ & $22.8 b$ \\
\hline Coco unfert + coffee fert & 21.1 & $23.6 b$ & $23.4 b$ & $22.2 b$ & $25.1 b$ & $17.9 \mathrm{c}$ & $17.7 b$ & $22.2 b$ \\
\hline Coco fert + coffee unfert & 22.9 & $28.1 \mathrm{ab}$ & $28.3 a$ & $25.4 a$ & $31.1 \mathrm{a}$ & $23.0 \mathrm{a}$ & $21.2 \mathrm{a}$ & $26.5 a$ \\
\hline Coco fert + coffee fert & 22.2 & $30.4 a$ & $26.3 a$ & 23.6ab & $30.2 a$ & $20.5 b$ & $21.0 \mathrm{a}$ & $25.5 a$ \\
\hline 0.05 & ns & 6.4 & 3.2 & 3.0 & 2.8 & 2.1 & 2.8 & 2.6 \\
\hline 0.01 & - & ns & 4.9 & ns & 4.2 & 3.2 & ns & ns \\
\hline C.V. & 13.9 & 16.9 & 9.0 & 9.1 & 7.1 & 7.6 & 10.5 & 7.7 \\
\hline
\end{tabular}

ns - not significant

Means having the same letter are not significantly different at 5\% level (LSD)

Appendix Table 4. Soil analysis at the end of the study (surface)

\begin{tabular}{|l|r|r|r|r|r|r|r|r|r|}
\hline \multirow{2}{*}{\multicolumn{1}{c|}{ Treatment }} & \multicolumn{9}{|c|}{ Exch Bases (m.e./100g) } \\
\cline { 2 - 11 } & $\mathrm{pH}$ & $\begin{array}{c}\mathrm{O} \text {.M } \\
(\%)\end{array}$ & \multicolumn{1}{c|}{$\mathrm{Ca}$} & $\mathrm{Mg}$ & $\mathrm{Na}$ & $\mathrm{K}$ & $\begin{array}{c}\text { Exch } \\
\text { Acid }\end{array}$ & $\begin{array}{c}\text { CEC } \\
\text { S un }\end{array}$ & $\begin{array}{c}\text { Base } \\
\text { Sat'n (\%) }\end{array}$ \\
\hline Coco unfert + coffee unfert & 4.6 & 2.16 & 6.5 & 2.9 & 0.03 & 0.45 & 12.98 & 22.83 & 43.17 \\
\hline Coco unfert + coffee fert & 4.6 & 1.67 & 6.1 & 2.7 & 0.03 & 0.50 & 13.64 & 22.93 & 40.56 \\
\hline Coco fert + coffee unfert & 4.7 & 1.92 & 6.1 & 2.6 & 0.03 & 0.51 & 13.35 & 22.44 & 40.84 \\
\hline Coco fert + coffee fert. & 4.6 & 1.67 & 5.6 & 2.8 & 0.03 & 0.41 & 12.85 & 21.77 & 41.22 \\
\hline
\end{tabular}

